\title{
State Terrorism and Globalization
}

\section{The Cases of Ethiopia and Sudan}

\author{
Asafa Jalata*
}

\begin{abstract}
This article compares the essence and effects of Ethiopian and Sudanese state terrorism by focusing on the commonalities between the two states. These peripheral African states have used global and regional connections and state terrorism as political tools for creating and maintaining the confluence of identity, religion, and political power. Ethiopia primarily depends on the West, and Sudan on the Middle East, since Christianity and Islam are the dominant religions in these African states respectively. While the Ethiopian state was formed by the alliance of Abyssinian (Amhara-Tigray) colonialism and European imperialism, the Sudanese state was created by British colonialism known as the AngloEgyptian condominium. Massive social and cultural destruction and violence have produced and maintained these colonial political structures. These structures, in turn, have racialized identities by facilitating the processes of Abyssinianization and Christianization in Ethiopia, Arabization and Islamization in Sudan, and Africanization and marginalization of indigenous Africans in both states. Furthermore, each state has been involved in ethnonational cleansing, which has been disguised rhetorically as a move toward national self-determination and democracy. Consequently, the racialization and ethnicization of these states, external dependency, and domestic terrorism have prevented the implementation of national self-determination and the construction of legitimate multinational democracies that could solve the political, social, cultural, and economic crises in Sudan and Ethiopia.
\end{abstract}

Keywords: genocide, globalization, marginalization, massive human rights violations, racism, religion, state terrorism

\section{Introduction}

In this article, I examine the essence of state terrorism in Ethiopia and Sudan in regional and global contexts. From the late 19th century to the present, the 'modern' Ethiopian and Sudanese states have been formed, consolidated, and maintained by state terrorism and global connections. The Ethiopian state was created by the alliance of Abyssinian (Amhara-Tigray) dependent colonialism

\footnotetext{
* University of Tennessee, Knoxville, USA.
}

Copyright (C) 2005 SAGE Publications www.sagepublications.com

(London, Thousand Oaks, and New Delhi)

Vol 46(1-2): 79-102. DOI: 10.1177/0020715205054471 
and European imperialism, and the Sudanese state by British colonialism known as the Anglo-Egyptian condominium. In both Sudan and Ethiopia, colonial political structures dominated by persons claiming Semitic descent emerged through a strategy of massive social and cultural destruction and political violence. Although Christianity is the main ideology of the Ethiopian state and Islam is the principal ideology of the Sudanese state, the elites and societies that have dominated the political structures in both countries share a strategy of racializing their own identities and those of indigenous Africans to Africanize and marginalize indigenous population groups and facilitate the process of Abyssinianization and Christianization in Ethiopia and Arabization and Islamization in Sudan. In addition, just as successive Ethiopian state elites have maintained their legitimacy and survival through external connections and domestic political terrorism, the Sudanese state elites that emerged through the process of decolonization in the mid-20th century have depended on external connections and terrorism for their legitimacy and survival.

First, I provide historical background to the processes of state formation in the two countries. Second, I explore the global, regional, and local processes through which the modern Ethiopian and Sudanese states emerged. Specifically, I demonstrate how global connections and state terrorism have been used as political tools for creating and maintaining the confluence of identity, religion, and political power; in other words, I examine the connection between terrorism, globalism, and the process of racialization and ethnicization of state power. Third, I explore state terrorism in Ethiopia and Sudan and conclude that in these two countries there can be no multicultural or multinational democracy, peace, stability, or development without removing the conditions that have facilitated external dependency and domestic terrorism.

\section{Historical Background}

Since ancient times, repeated episodes of migration from Arabia have led to a series of conflicts revolving around issues of religion, identity, land, and power between indigenous African population groups and the Africanized Arab descendants in the countries that today are called Ethiopia and Sudan. The modern ideology of the Ethiopian state evolved from what was once the Axumite Kingdom of Abyssinia, which Africanized descendants of Arab settlers formed in the first century AD (Michels, 1991). The Axumite Kingdom accepted Orthodox Christianity in the fourth century through the commercial relationship it developed with the Greco-Romans. However, Muslim Arab immigrants who arrived after the rise of Islam in the seventh century subsequently challenged the Axumites and spread this new religion throughout African coastal towns. As Islamic influence increased, the commerce of the Axumite Kingdom started to decline. In the mid-11th century, the previously colonized Agao people established a kingdom known as the Zagwe Dynasty by overthrowing 
the Axumite Kingdom. This dynasty lasted until 1270, when it was overthrown by one of the groups that descended from the remnants of the Axumites. These Axumite descendants developed a separate identity known as Amhara.

The Amhara ethnonational group and another group known as Tigray are collectively called Habashas or Abyssinians. The Habashas developed a common religion, tradition, and set of customs, but the Amhara and Tigray have maintained different languages. Although phenotypically and culturally Africanized, the Habashas have suppressed their Africanness by linking themselves to the Middle East and by considering themselves racially and culturally superior to indigenous Africans (Jalata, 2001). Using their state power, the Habashas imposed their Christian religion, their languages - Amharic or Tigragna - and their customs on the peoples they colonized, resulting in Abyssinianization, which I have described as the complete destruction of the identity of the colonized population groups by claiming racial and/or cultural superiority (Jalata, 1993).

Arab immigrants and their Africanized descendants also culturally, politically, and religiously marked the country known as Sudan, the northern part of which was once the famous indigenous kingdom of Nubia. Nubians had trade connections with the Arabs before the emergence of Islam, and with the decline of the Nubian civilization and the division of its kingdom, the number of Muslim Arab immigrants increased in Nubia. A signed treaty with Arabs who colonized Egypt in AD 640 led to the peaceful migration of more Arabs into Nubia, who gradually colonized the kingdom. There were four immigration waves from Arabia to this region: immigration through Egypt in the seventh and eighth centuries (MacMichael, 1967), immigration through Abyssinia in the eighth century, a third immigration wave in the 13th and 14th centuries (MacMichael, 1967), and a fourth immigration wave following the emergence of the Funj Kingdom.

The Funj Kingdom was founded in AD 1504 by the descendants of Arab immigrants who overthrew the Kingdom of Christian Nubia (Adams, 1977). For the Arab immigrants and their descendants, the Funj Kingdom 'became a guarantee of peace and order' (Adams, 1977: 14), but for the original Africans, it became the tool of destruction. Most Nubians remained Christian until the 15 th or 16th century, when the newcomers introduced their system of racialized politics and religion. Between 1504 and 1820, the kingdom 'institutionalized Islam and it developed into the official religion' (Ibrahim, 1979: 8). Generally speaking, Arab immigrants and their Africanized descendants developed racialized identities and introduced to the Horn of Africa politicized religions, Orthodox Christianity and Islam, which proved to be problematic for the construction of legitimate and multicultural democratic societies. The original Africans, in particular, were negatively affected by Abyssinianization and Christianization and by Arabization and Islamization, respectively, in the areas that later emerged as Abyssinia/Ethiopia and Sudan. 
Indigenous Africans had various social and cultural formations. Different ethnonational communities had varying forms of state formation processes, including kingdoms, democracies, and lineage and kinship political systems. The Oromo were one of the peoples that practiced an indigenous popular democratic system called Gada, or Oromo democracy (Legesse, 1973, 2000). ${ }^{1}$ American anthropologist Bonnie Holcomb (1991: 1-10) notes that the Gada system 'organized the Oromo people in an all-encompassing democratic republic even before the few European pilgrims arrived from England on the shores of North America and only later built a democracy.' Each indigenous society fought but failed to protect its homeland and people from the invaders. Over the last five centuries, conflicts and wars having international dimensions have been frequently recorded in the Horn of Africa (Jalata, 1993). The Arabs and the Ottoman Empire dominated the commercial activities of the Horn until European imperialism expanded to the region.

This capitalist penetration laid the foundations for the modern Ethiopian and Sudanese states. Oromia (the Oromo country) was partitioned between Britain and Ethiopia; Somaliland was divided among Britain, France, Italy, and Abyssinia; Sudan was occupied by Britain; and the Afar country was partitioned between France, Italy, and Abyssinia. While other Africans were denied the opportunity to buy firearms on suspicion that they would be used against Europeans, because of their collaboration with the European imperialists and because of their Christian religion, the Habasha (Ethiopian) rulers were allowed to buy firearms and participate in the Scramble for Africa (Beachey, 1962). The modern Ethiopian state emerged from the alliance of Ethiopian colonialism and European imperialism, while the modern Sudanese state developed after the decolonization of Sudan in 1956.

\section{The Emergence of the Modern Ethiopian and Sudanese States}

The practice of creating and supporting a neocolonial state in accordance with the interests of the racialized capitalist world system started with the emergence of the modern Ethiopian state in Africa (Jalata, 1993, 2001). Because of their Christian ideology and the willingness to collaborate with European imperialist powers, successive Habasha rulers received access to European technology, weapons, administrative and military expertise, and other skills needed for the construction of the modern state (Holcomb and Ibssa, 1990; Jalata, 1993). Consequently, Ethiopian warlords participated in the scramble for Africa. The main reason for this colonial expansion was to obtain commodities such as gold, ivory, coffee, musk, hides and skins, slaves, and land. The emerging Ethiopian state committed genocide on peoples such as the Oromo to obtain these materials. Between 1868 and 1900, when Oromia was effectively colonized by Abyssinia, the Menelik forces reduced the Oromo population from 10 to 5 million; war, slavery, famine, and diseases contributed to the destruction of the Oromo people (Bulatovich, 2000; 
Jalata, 1993), but we do not know how many Somali, Afar, Sidama, and others were decimated during this colonial occupation. The Haile Selassie, Mengistu and Meles regimes have continued these genocidal practices (Jalata, 1993).

The racialized/ethnicized modern state of Sudan also developed from the expansion of the European-dominated capitalist world economy in the form of British colonization. When, in the mid-1950s, various Sudanese political forces demanded their rights of national self-determination, the British colonial government announced its intention to decolonize Sudan. Since the British relinquished power, successive racialized/ethnicized Sudanese regimes - civil or military - have imposed their political authority through repression and terrorism to possess absolute control over the means of compulsion (the state) and the means of consumption (productive resources). As Besteman (1999: 129) explains:

global racial categories elaborated during the colonial period reinforced preexisting local ethnic construction, ensuring a national hierarchization of ethnicities and their accompanying privileges, statuses, rights, and meaning within the political community condensed into being by postcolonial state power.

European colonialism and the imperial interstate system have created and consolidated racialized/ethnicized states or 'authoritarian-terrorist' regimes in both countries. Each has been viewed as an authoritarian regime by the respective ethnonation from which it emerged and as terrorist by the racialized political minorities it suppresses and exploits. These authoritarian-terrorist regimes are characterized by extreme militarization and repression; tight control of information and resources in the form of foreign aid, domestic financial resources, and political appointments; and direct ownership and control of all aspects of state power, including security and military institutions, judiciary and other public bodies, and financial institutions (Besteman, 1999; Jalata, 2000). As the Ethiopian state has been Abyssinianized and Christianized to exclude non-Habashas from decision-making power, the Sudanese state has been Islamized and Arabized to exclude indigenous Africans from state power. These authoritarian-terrorist regimes have been supported by powerful global or regional powers and the imperial interstate system.

\section{The Discourse of Racism, Ethiopian State Terrorism, and Global Tyranny}

State terrorism is a systematic governmental policy in which massive violence is practiced against a given population group with the goal of eliminating any behavior that promotes political struggle or resistance by members of that group. Any state that engages in terrorism is not a protector of citizens; rather, it violates civil and human rights through assassinations, mass killings, and imprisonments, often along with a display of corpses in the streets so that the remaining population will accept the violent state out of terror and 
intimidation. The main assumption of such a state is that it can control the population by destroying its leaders and the culture of resistance. States that fail to establish hegemony by accountable democratic political order are unstable and insecure; hence, they engage in state terrorism (Oliverio, 1997).

Successive Ethiopian authoritarian-terrorist regimes have used the discourses of race, culture, and Christianity to link themselves to the Middle East, Europe, and North America and to consolidate their power against fellow Ethiopians and the colonized populations, such as the Oromo, Sidama, OgadenSomali, and Walayita. Habashas have effectively used racism, which combines the discourses of biological and cultural differences to justify unequal treatment of different population groups, to destroy or suppress colonized peoples (Jalata, 2001). Globally, the Habashas have used Semitic and Christian discourses to mobilize assistance from Jews, Arabs, Europeans, and Americans who see Habashas closer to themselves than the peoples whom they consider 'real black' (Jalata, 2001) and consider them closer to 'the European race' or members of 'the great Caucasian family' (quoted in Marcus, 1996: 5). ${ }^{2}$

Ancient Ethiopia was the name of the black world as a whole. Because most people do not know the difference between ancient Ethiopia and contemporary Ethiopia, the Habashas have been able to use their blackness to mobilize other Africans, the African diaspora (Scott, 1993), and black US policy elites against the Oromo and other colonized peoples (Jalata, 2001). Recognizing the political significance of the name Ethiopia, the Abyssinians officially adopted the name in the 1930s, although they developed a racialized identity that differentiated them from the original Africans whom they saw as real blacks. Because the Habashas maintained formal political power, Africans who were colonized and enslaved by Europeans wrongly considered contemporary Ethiopia as an island of black freedom. Most blacks 'knew very little about the social and political conditions of Ethiopia. What they wrote or said about Ethiopia was at best a manifestation of their emotional state' (Scott, 1993: 26). Other Africans were unaware that Ethiopia's political power came from allying with the colonizing European powers.

In reality, the Ethiopia that participated in the slave trade and the Scramble for Africa was not an island of black freedom but a 'prison house' in which colonized and enslaved peoples were and still are brutalized. Even though Habashas are black, they present themselves as Semitic to associate themselves with the Middle East and dissociate themselves from Africa, whose peoples they consider both racially and culturally inferior. Sorenson (1993: 29) expresses this racist attitude as 'a multiplicity of Ethiopians, blacks who are whites, the quintessential Africans who reject African identity.' Since the concept of race is a sociopolitical construct, it is essential to critically understand the historical context in which Ethiopian racism is produced and reproduced to denigrate colonized peoples and to deny them access to Ethiopian state power by practicing state terrorism. In Ethiopian discourse, so-called racial distinctions such as Semitic, 
Hamitic, Negroid, and Cushitic are manipulated to perpetuate the political objective of Habasha domination of the colonized population groups. Habasha elites have recognized the importance of racial distinctions and used the discourse of racism to mobilize support for their political projects (Sorenson, 1998).

Ethiopian racism and white racism have conveniently intermarried in US policy formulation and implementation in Ethiopia. When policy issues are discussed, ideologies such as Semitic civility, Christianity, and the patriotism of Amharas and Tigrayans are used to valorize and legitimize Habasha dominance and power. Moreover, the façade of barbarism, backwardness, and destructiveness of the Oromo and other indigenous Africans is reinvented to deny them access to state power (Jalata, 2001). The Ethiopian government has historically obtained its political legitimacy and financed its engagement in human rights violations through global connections. Just as Britain supported Ethiopia during the first half of the 20th century, the United States provided financial assistance to the Haile Selassie government from the mid-20th century to the mid-1970s. Subsequently, from the mid-1970s to 1991, the Soviet Union supported the Ethiopian military regime headed by Mengistu Haile Mariam, which brought untold misery, war, famine, and terrorism to various population groups in Ethiopia. The financing provided from these external resources enabled successive Ethiopian states to engage in terrorism.

When the military regime collapsed in 1991, the United States financed the Tigrayan organization, the Tigrayan People's Liberation Front (TPLF), which emerged from the Tigrayan ethnonational group, and diplomatically assisted Meles Zenawi to replace Mengistu Haile Mariam. The successive regimes of Menelik, Haile Selassie, Mengistu, and Meles have been racist and dictatorial and have continuously pursued destructive policies that have intensified war, terrorism, underdevelopment, and poverty and have denied the people subsistence, protection, and development (Shiffman, 1995). Consequently, the people do not have adequate income, food and habitable homes, or access to health and medical services. Moreover, they have no protection from political violence, because the Ethiopian state engages in massive human rights violations and terrorism (Jalata, 2000).

As with the previous states, the current Ethiopian state mainly obtains its political legitimacy from global connections. In addition to financing with Israel the flight of Mengistu in 1991, the United States supported the creation of the Ethiopian People's Revolutionary Democratic Front (EPRDF) by the Tigrayan People's Liberation Front (TPLF) and endorsed the emergence of the Meles regime. Along with other western countries, the United States still provides significant assistance to the regime. Human Rights Watch/World Report 1999 (1999: 3) states:

With about $\$ 30$ million in development aid and \$66 million in food aid, bringing the total to about $\$ 97$ million, Ethiopia remained the second largest recipient 
of US aid in sub-Saharan Africa, after South Africa. The US failed to use its privileged relations with Ethiopia as a leverage for human rights improvements.

US foreign policymakers support regimes like that of Ethiopia in the perceived strategic and economic self-interest of the United States and have no interest in developing a more critical understanding of the political context in which they have become involved.

Currently, the main rationale for the involvement of US policymakers with regard to Ethiopia is to maintain political order and to enlist it in the fight against global terrorism. Ironically, the US government cannot effectively deal with global terrorism because it practices a double standard: It condones the terrorism of friendly states such as that of Ethiopia and Israel while simultaneously complaining about other forms of terrorism. US foreign-policy experts are more concerned with political order, economic reforms, and existence of regimes such as that of Ethiopia at any cost and care less about democracy and human rights. The Economist (1997: 36) notes that Meles Zenawi:

is regarded as one of Africa's 'new leaders': he recently won an award in the United States for good government ... Their [western] governments tend to give priority to the Prime Minister's economic reforms rather than his record on human rights.

The intensification of globalization through various technological and information revolutions has not changed the underlying status of colonized peoples like the Oromo. Rather, it has increased their exploitation and repression by enabling the regime in power to use the Internet and other communication and information networks to keep the Oromo under 'Ethiopian political slavery' and to ally the Ethiopian state with transnational capital. The Oromo and others are denied the freedom of self-expression and self-development and are forced to provide their economic and labor resources to the Ethiopian colonizers and their supporters and to live under deplorable conditions. Using political violence, the Tigrayan authoritarian-terrorist regime has dominated and controlled the Oromo and denied them the freedom of expression, association, and organization, as well as access to the media and related forms of communication and information networks. The Meles regime has used various techniques of violence to terrorize colonized peoples like the Oromo. Former prisoners have testified to incidents of being whipped or tortured, being locked in steel barrels, and being forced into pits where fire was made on top of them; others have reported that large containers or bottles filled with water were fixed to their testicles, or if they were women, bottles or poles were pushed into their vaginas (Fossati et al., 1996). TPLF/EPRDF soldiers have openly shot thousands of people in rural Oromia - leaving their bodies for hyenas, burying them in mass graves, or throwing their corpses off cliffs.

Other methods of killing include burning, bombing, cutting throats or 
arteries in the neck, strangulation, and burying people up to their necks in the ground. Hassen (2001) estimates that between 1992 and 2001 about 50,000 killings and 16,000 disappearances (euphemism for secret killings) took place in Oromia alone. Further, he estimates that 90 percent of the killings are not reported. To hide these criminal practices from the world community, the Meles government 'does not keep written records of its extrajudicial executions and the prolonged detention of political prisoners' (quoted in Hassen, 2001: 33). The Meles regime has killed Oromo who engaged in peaceful demonstrations. For instance, on 25 March 1992, in the town of Watar, Hararghe, the soldiers of the regime massacred 92 Oromo and wounded more than 300.

Hassan Ali, an Oromo collaborator with the Meles regime who subsequently fled and resettled in the United States, describes the criminal activities of the soldiers as follows:

The TPLF soldiers and its members are a law unto themselves. Only what they say and what they want is implemented in Oromia to the general exclusion of Oromo interests or wishes ... Although Oromia is autonomous in name, the government soldiers and secret service agents have total power to do whatever they want in Oromia. They imprison, torture, or kill anyone ... without any due process of law. They have established several secret detention centers, where thousands of innocent people are kept for years without trial or charge. (quoted in Hassen, 2001: 33)

TPLF/EPRDF soldiers have killed several pregnant women and hundreds of Oromo children between the ages of 12 and 16. According to the Oromia Support Group (1997: 8):

a 7-month pregnant woman in Robe, Bale, was arrested and beaten ... She miscarried and later died in custody. When relatives went to claim her body, they were told to replace the remains with a living relative. When asked to explain, the TPLF soldiers said, 'She died with OLF objectives still stuck in her brain and we could not get what we wanted from her.'

The Ethiopian government has used state terrorism to commit genocide on the Oromo and other indigenous peoples.

Article II of the United Nations Convention (1948) defines genocide as 'acts committed with intent to destroy, in whole or in part, a national, ethnical, racial or religious group.' Chalk and Jonassohn identify two major types of genocide (1990): the first type is used to colonize and maintain an empire by actually terrorizing people perceived to be real or potential enemies. In this case, the main purpose of practicing genocide is to acquire land and other valuable resources. The second type of genocide, ideological genocide, involves the maintenance of colonial domination by state elites through the establishment of hegemony practiced through genocidal massacres to prevent the resistance of the dominated groups. Jonassohn (1998: 23) notes that ideological 
genocide develops 'in nation-states where ethnic groups develop chauvinistic ideas about their superiority and exclusiveness.'

As the Amhara-dominated successive regimes engaged in terrorism and genocide and exploited the resources of the Oromo, Afar, Ogaden-Somali, Sidama and Walayita, the Tigrayan-dominated regime is engaged in similar practices to suppress the national movements of these indigenous peoples in order to continue their domination and exploitation. With the intensification of the national movements of the Oromo, Sidama, Afar, and Annuak, the Tigrayandominated regime has been engaged in massive human rights violations, terrorism, and genocide. The Meles regime has been using war, torture, rape, and other mechanisms of violence to fulfill its political objectives. While engaging in political violence in the form of state terrorism, state rape, and hidden genocide to control the Oromo people and others and loot their economic resources, the Tigrayan state elites claim that they are promoting democracy, federalism, and national self-determination. The Meles regime believes that Oromo intellectuals, businessmen and women, and community and religious leaders are the enemy of the 'Ethiopian revolution.' In its propaganda pamphlet known as Hizbawi Adera (1996/1997), the regime claims that Oromo leaders have endangered the processes of peace, democracy, and development by promoting what it calls narrow nationalism. Sagalee Haara (1998: 6) notes that 'recent murders and disappearances of Oromo and the detention of members of the Macha/Tulama Association and the Human Rights League are part of the implementation of policies put forward in this document.'

When it attempts to eliminate the Oromo elite through hidden genocide to deny the Oromo a leadership, this racist regime prepares the Tigrayan children for the position of leadership by providing better education while denying an appropriate educational opportunity for the Oromo children. ${ }^{3}$ Hundreds of Oromo business people have been harassed, killed, or imprisoned and robbed of their properties. Similarly, hundreds of Oromo intellectuals have been harassed or killed or forced into exile. The regime expelled more than 300 Oromo students from the Addis Ababa University and other colleges and imprisoned or killed their leaders for peacefully demonstrating on 21 January 2004. Saman Zia-Zarifi (2004: 1), the academic freedom director at Human Rights Watch, says, 'Shooting at unarmed students is a shameful misuse of government power.'

Despite its adoption in its constitution, the principles of the Universal Declaration of Human Rights and International Covenants on Human Rights, the Meles government engages in terrorism and gross human rights violations. The TPLF/EPRDF government accepts state violence against Oromo, Sidama, Annuak, Somali, and others as a legitimate means of establishing political stability and order. Welsh (2002: 67-8) suggests that since weak states 'lack the capacity to meet the demands and rights of citizens and improve the standard of living for the majority of population,' they engage in political violence and in 
genocidal massacres to suppress the population groups that struggle for political and economic rights. Because of their economic resources, the size of their population, and their resistance in challenging the racist policy of this regime, the Oromo are targeted for destruction. As Sharlach (2002: 107) attests, genocide occurs when a politically 'dominant group, frightened by what its members perceive as an onslaught of international and internal movements for democracy and socioeconomic change, harnesses the state apparatus to destroy the subordinate group altogether.' The Meles government sees Oromia as part of its empire, controls all Oromian resources, and practices terrorism and genocide against the Oromo people since it perceives them as its potential or real enemies.

The Tigrayan elites are imposing their political ideologies, such as 'revolutionary democracy' and 'federalism,' to legitimate Tigrayan ethnocracy and state power through genocidal massacres to control the Oromo and other population groups and their resources by eliminating their leadership. The regime has been hiding its genocidal practices and terrorist activities. Jonassohn's (1998: 11) description of the conspiracy of 'collective denial' of genocide by perpetrators captures this reality:

There are many reasons for this: (a) in many societies such materials are not written down, or are destroyed rather than preserved in archives; (b) many perpetrators have recourse to elaborate means of hiding the truth, controlling access to information, and spreading carefully contrived disinformation; and (c) historically, most genocides were not reported because ... there appears to have existed a sort of conspiracy of 'collective denial' whereby the disappearance of a people did not seem to require comment or even mention.

The government of Ethiopia committed genocide on the Annuak people of Gambella in December 2003 and 2004. In the letter it sent to Prime Minster Meles Zenawi on 8 January 2004, the International Campaign to End Genocide notes that massacring people:

because of their ethnic group membership is genocidal. The Genocidal Convention outlaws the intentional destruction of part of an ethnic group, not just the destruction of the whole group... We ask that you now arrest and try the perpetrators of the December massacre of Annuak in Gambella.

State-sanctioned rape is a form of terrorism in Ethiopia. The use of sexual violence is a tactic of genocide that a dominant ethnonational group practices in destroying the subordinate ethnonational group (Sharlach, 2002). Genocide studies ignore:

the full extent of the humiliation of the ethnic group through the rape of its women, the symbols of honor and vessels of culture. When a woman's honor is tarnished through illicit intercourse, even if against her will, the ethnic group is also dishonored. The after effects of rape, forced impregnation, psychological 
trauma, degradation, and demoralization go beyond the rape victims themselves. (Sharlach, 2002: 107)

The Tigrayan cadres, soldiers, and officials frequently rape Oromo girls and women to demoralize the Oromo and show that the Tigrayan rulers wield boundless power. Many of the rape survivors have contracted diseases, such as syphilis, gonorrhea, and AIDS. MacKinnon's (1994: 11-12) comment regarding ethnic cleansing in Croatia and Bosnia-Herzegovina applies equally to the rape of Oromo women: 'It is rape to drive a wedge through a community, to shatter a society, to destroy a people. It is rape as genocide.'

The Tigrayan regime has targeted all sectors of Oromo society to destroy the foundation of Oromo nationalism and political struggle. In Ethiopia, where neither freedom of expression nor free media exist, people choose to be quiet to save their lives even if their relatives are killed by the government. The Ethiopian state elites who have been engaged in gross human rights violations and genocide like other criminal leaders in peripheral countries:

not only go unpunished, they are even rewarded. On the international scene they are accorded all the respect and courtesies due to government officials. They are treated in accordance with diplomatic protocol in negotiations and seated in the General Assembly of the United Nations. When they are finally ousted from their offices, they are offered asylum by countries that lack respect for international law, but have a great deal of respect for the ill-gotten wealth that such perpetrators bring with them. (Jonassohn, 1998: 24)

The Tigrayan-dominated regime banned independent Oromo organizations, including the Oromo Liberation Front, in 1992, and declared war on these organizations and the Oromo people. It even outlawed musical groups and professional associations and closed down Oromo newspapers. Attempting to make the Oromo voiceless, as previous Ethiopian governments have done, the Meles government has left Oromo without any form of organization and institution. Only the organizations and the media that are owned and controlled by the Tigrayan government have remained intact, serving to impose the Tigrayan colonial and racist authority in Oromia and other colonized regions. The regime has engaged in political crimes, genocidal massacres, and state terrorism with little or no opposition from western powers, particularly the United States. How long will international bodies continue to ignore these problems? Are they waiting for a full genocide to emerge? Let us now turn to Sudan and examine the connection between racism, Islamism and state terrorism.

\section{Racism, Islamism, and State Terrorism in Sudan}

The modern Sudanese state was created through the broadening of the European-dominated racialized capitalist world system via British colonization. 
Since the transfer of state power to the Arabized northern Sudanese elites in 1956, northern Sudanese elites have practiced slavery, colonialism, and continued subjugation on various Sudanese population groups. In these practices, racism and Islamism have been used as twin ideologies. Before the colonization of Sudan by Britain, the Turko-Egyptian conquest laid the foundation for a central state in northern Sudan. A northern Sudanese movement known as the Madia dismantled the Turko-Egyptian rule and ruled northern Sudan until Britain colonized Sudan. Madism 'was both a religious and a political movement which aimed at a return to the Orthodox Islamic constitution in government, culture, and religion' (El Mahdi, 1965: 19).

Northern Sudanese elites enslaved population groups that they considered unbelievers and racially and culturally inferior; they used the sword and the Koran to commodify human beings. They burned houses and destroyed communities to hunt and enslave the southern and other Sudanese. Arab slave traders from northern Sudan and other countries settled in the south and other places and intensified the slave trade and social destruction with the help of the state. According to Fluehr-Lobban (1991: 73), 'slavery was conducted for both military and commercial purposes. The Turko-Egyptian armies depended on regular slave raiding, and the demand for domestic slaves in Egypt, the Ottoman Empire, and Arabia was continuous.' More than 2 million people were sold during the 19th century (O'Ballance, 1977: 20). Northern Sudanese

merchants went south demanding huge deliveries of slaves, ivory and feathers and in doing so devastated the area, burning villages and farms, encouraging [inter-ethnonational] wars so that one [ethnonation] made deliveries at the expense of the other. This situation which lasted for ... [more than] 50 years made stable life and progress impossible in the south. (Garang, 1985: 23)

Slavery created long-lasting historical contradictions in Sudan. FluehrLobban (1991: 72) argues that:

the complex role that the nineteenth-century slave trade played in laying the foundation for the fear of the foreigner and the trader from the north, together with a belief that the trader was Muslim and condoned by Islam, laid the basis and set the agenda for north-south suspicions and divisions that have continued to define relations from the nineteenth century to present.

Prior to the colonization of Sudan by Britain, the northern Sudanese elites could not effectively occupy the south (Holt and Daly, 1979); however, they sometimes raided it (Woodward, 1994). O'Ballance (1977: 24) notes that 'wherever possible the Mahdi attempted to force the Islamic religion on the southerners, which caused hostility, and also legalized slavery.' During the Turko-Egyptian and Mahdist regimes, 'social progress was arrested in the south, for the same reasons trade flourished in the north, towns appeared along the Nile, and on the Red Sea. This was the beginning of uneven development between the two parts of 
the country' (Garang, 1985: 22). Further, the Anglo-Egyptian condominium that ruled Sudan from 1899 to 1956 widened the inequality between the north and the south.

Although the British administration abolished slavery, its policies favored the north and expanded colonial capitalist development in that region. In the south and other places, development issues were largely ignored. For instance, there were only five university graduates and one secondary school in the south when Sudan gained its independence in 1956 (Garang, 1985). Thus the southern and other Sudanese were not only economically exploited but denied education by the British. When Britain was forced to leave Sudan by anticolonial forces, the south and other regions came under the control of the north, and the south's demand for a federation was ignored and a unitary state was imposed. According to Garang (1985: 23-4):

The British official in the south was replaced by a northern official because Britain had not trained southerners for the job. The southern market fell to northern merchants who bought food and other crops cheaply from the southerners and [in return] sold them expensive European goods.

The system of southern education was changed; Arabic became the official language, and the north practically occupied state power (O'Ballance, 1977). Although decolonization 'itself resulted from an act of the Constituent Assembly, freely and fairly elected in 1953 by any reasonable standard' (Bechtold, 1991: 3), the new Sudanese government 'sought to impose Arabization and Islamization on the south in an attempt to achieve national unity through uniformity' (Deng, 1991: 25).

The southern Sudanese resisted both Turko-Egyptian and northern Sudanese colonialism in the 19th century. They fiercely resisted the Madist army and forced it to withdraw from the south in 1897 (O'Ballance, 1977). Similarly, they opposed British colonialism and its policy of creating a hereditary chief. Numerous revolts occurred during the first half of the 20th century. In the early 1920 s, the south began to create protonationalist organizations, such as the Sudanese United Tribes Society and the White Flag League. The south also continued its resistance to northern domination after the modern Sudanese state emerged. Nevertheless, northern politicians ignored the interests of the south and other regions. O'Ballance (1977: 40) states that:

the increasing pace of Sudanization (which to the southerner means northernization) caused unrest and discontent in the south ... To the southerners it appeared as if they were being colonized for the second time. Both the army and the police in the south ... were now heavily officered by northerners.

Grievances such as increasing the number of northern troops in the south and the attempt to transfer southern soldiers to the north led to mutiny. Deng (1991: 24) comments that: 
the conflict erupted in August 1955 when a mutiny by one southern battalion was triggered by a widely shared fear in the south that independence was going to mean a change of masters - from the British to the Arabs - and could entail the return of the slave trade in which blacks were the victims of the Arab north.

The mutineers, who escaped imprisonment and execution by fleeing into the forest, began to initiate guerrilla warfare against the Sudanese state. The continued state repression of the south and indiscriminate killings of civilians for allegedly harboring the guerrilla fighters facilitated the development of southern nationalism. To curb that impulse, the state intensified its Arabization and Islamization policies: it nationalized private schools, prohibited missionary schools in 1957, and, in 1960, replaced the Sunday weekly holiday with Muslim Friday.

With the emergence of a resistance movement and a continuation of the demand for independence or federation, the state increased its political terrorism on the south. Because of brutal repression, many government employees and soldiers deserted the government and joined a movement known as the Anya-Nya. In 1971 the Anya-Nya became the Southern Sudan Liberation Movement (SSLM). This organization reached a negotiated political settlement with the Numayri government in 1972. The south accepted regional autonomy set forth in the Addis Ababa Peace Agreement and abandoned its demand for a separate army. In 1983, President Numaryi changed his mind and introduced the rule of sharia, or Islamic law. Numaryi divided the south into three regions thus violating the 1972 Addis Ababa Peace Agreement.

Consequently, the second phase of the struggle of the south started under the leadership of the Sudan People's Liberation Movement (SPLM) and its military unit, the Sudan People's Liberation Army (SPLA). As the resistance increased, the south was exposed to mass poverty, economic and cultural dislocation, unemployment, recurring famine and disaster, war, and state terrorism. This political terrorism manifested itself in the form of summary executions, assassinations, mass imprisonments, rape, forced dislocation into concentration camps, constant destruction of houses, farms, and villages, robbery and theft, and militarization of rural communities (Amnesty International, 1995/96; Prendergast and Bickel, 1994; Walgren, 1994). Today, the Sudanese government continues to use state terrorism and famine to crush the resistance struggles of southern and western Sudan. According to Prendergast (2004a: 1):

the government's helicopter gunships are blowing bombs and bullets into southern villages, while the opposition Sudan People's Liberation Army conducts ground raids on the oil industry infrastructure that helps pay for the state's helicopters. Relief agencies, banned from many areas by the government, are begging for access to deliver food aid to a million people dependent on them for survival. More bodies are added to the shocking two million victims of violence and famine in Sudan's 19-year civil war. 
The conflict between northern and southern Sudanese displaced 4.5 million people, compounded the famine crises, and increased the suffering and misery of the victims (Prendergast, 2004a). The conflict has been:

between the central government, dominated by a well-armed and well-funded Arab Islamist elite, and southern insurgents opposed to the regime. Sudan's vast oil reserves, currently controlled by the government, are the greatest spoils of the war, but it is also a battle over land, religion, ideology and demands for selfdetermination. (Prendergast, 2004a: 1)

The conflict in Sudan sometimes goes beyond the south and north and religion and identity. This conflict also has taken place among Muslims, not simply between Christians and Muslims, since 'a small group from the center of the country maintains power by any means necessary’ (Prendergast, 2004b: 1). The peoples of west Sudan who are currently facing state terrorism and genocide are Muslims, although they are not Arabized Muslims.

Prendergast (2004b: 1) notes that 'Sudan is Rwanda in slow motion.' The Sudanese state created 'the second largest death toll since World War II (the conflict with the SPLA), and it 'is responsible for creating the worst humanitarian crisis in ... Darfur' in 2003 and 2004. When two Darfurian rebel groups in western Sudan, namely, the Sudan Liberation Movement/Army (SLM/A) and the Justice and Equality Movement (JEM), attacked military garrisons in western Sudan in February 2003, the government mobilized, armed, and unleashed a terrorist militia group known as 'Janjaweed' (Arab militia) to collectively punish the peoples of the Fur, Zaghawa, and Massalit. As of 19 November 2004, public television reports from the United States estimate that about 70,000 people have been killed by Janjaweed militia and state soldiers in west Sudan. According to Mozersky (2004: 1), these militia attacks have produced untold human atrocities:

Part of a scorched-earth government offensive, Janjaweed attacks have led to massive displacement, indiscriminate killings, looting and mass rape. These have been characterized as ethnic cleansing by many observers and compared to the Rwandan genocide by the former head of the United Nations in Sudan.

To date, more than one million residents of Darfur have been displaced, many now living in squalid camps, where they are dying from disease and malnutrition. Another 110,000 have crossed into neighbouring Chad, though even there they are not safe from Janjaweed attacks.

The Arabized Sudanese state has been using state terrorism to resolve the political, social, and economic crises in Sudan. This state receives political and financial support from Arab countries (Oxford Analytica, 2004). 


\section{Comparing the Two Cases}

State terrorism is associated with the issues of control of territory and resources and the construction of political and ideological domination. Oliverio (1997: 52) explains two essential features of state terrorism:

First, the state reinforces the use of violence as a viable, effective, mitigating factor for managing conflict; second, such a view is reinforced by culturally constructed and socially organized processes, expressed through symbolic forms, and related in complex ways to present social interests. Within increasing economic and environmental globalization, gender politics, and the resurgence of nationalities within territorial boundaries, the discourse of terrorism, as a practice of statecraft, is crucial to the construction of political boundaries. As such, terrorism is invoked in the art of statecraft when multiple, often conflicting versions of the past are produced and, at particular historical moments, become sites of intense struggles.

Ethiopian and Sudanese state elites have been determined to maintain existing political and economic order by investing meager available resources in building unproductive institutions, such as the army, security infrastructure, and bureaucracy, and using them in imposing state terrorism on their subjects in Ethiopia and Sudan, respectively. The behavior of these elites has been shaped by predatory political cultures that have been tyrannical, racist, and parasitic. Consequently, political elites in the two countries have failed to advance peaceful and meaningful socioeconomic development, to resolve fundamental contradictions between the dominant and the dominated ethnonational groups, and to recognize principles of self-determination and multinational democracy. Rather, they have chosen state terrorism to promote their political objectives.

As Christians, Habashas have been enjoying the sympathy and support of the West, while the northern Sudanese Muslims have been receiving assistance from Muslim states. Consequently, both states have ignored domestic political legitimacy. The identification of the Sudanese government with the Arab world rather than with Africa has strengthened the relationship of this state with the Arab states. For many decades, 'the Arab states have been an important source of economic, military, and political assistance. Such assistance has been especially helpful to Sudan's governments when they have been internationally beleaguered or under pressure in the country's long-running civil war' (Oxford Analytica, 2004: 1). Of all Arab countries, Egypt has the greatest strategic and economic interest in Sudan because of its reliance on the Nile, which originates in Sudan. Following Egypt, Libya and Saudi Arabia have the second greatest interest in Sudan:

For Libya, Sudan constitutes a potential ally in its on-off rivalry with Egypt. Otherwise its principal interest in Sudan is, as for Saudi Arabia, that the country 
should not be a political threat. Libya and Saudi Arabia therefore share with Egypt a preference for Sudan to be ruled by a stable military regime, rather than a democratic government or, worst of all, a revolutionary Islamist regime such as ruled Sudan in the 1990s and which supported Islamist opposition groups in the region. (Oxford Analytica, 2004: 2)

While Sudan is strategically important for some Arab countries, Ethiopia is strategically significant for western countries in general and for the United States in particular. Therefore, these western countries are more interested in supporting regimes that they can easily maneuver rather than democratic governments that have domestic legitimacy and can resist external dependency (Jalata, 2001). The Meles regime is in power predominantly because it receives financial and military support from the United States and other western countries. For example, Impact International (1997: 1) notes that the US government:

agreed in July 1996 to supply Ethiopia 50 fighter aircrafts and a number of helicopter gun ships. After signing the agreement, a Pentagon spokesman described Prime Minister Meles Zenawi as [a] 'trusted and important friend of America ... the Ethiopian leader was the only one in the region' whom they could depend upon to counter the menace of fundamentalism.

The United States, other western countries, and Israel use the discourse of Islamic fundamentalism to support the authoritarian-terrorist regime of Meles Zenaw and to suppress the national struggles of Oromo and others for selfdetermination and multinational democracy (Africa Confidential, 1997; Jalata, 2001). The regional and international supporters of these states have directly or indirectly contributed to serious human tragedies that have significant consequences for the Horn of Africa. Although global powers are concerned about the political crisis in Sudan because they oppose the Islamist Sudanese regime, they rarely show any concern about state terrorism in Ethiopia.

As President Numaryi adopted the rhetoric of socialism and regional autonomy and established a temporary peace with the south between 1972 and 1983, the Meles regime established a coalition transitional government with the Oromo Liberation Front (OLF) and other political organizations between 1991 and 1992. Although Numaryi won the confidence of the south during this period and established consensual domination (Gramsci, 1971) over the south, he returned to coercive domination by reintroducing the policy of Islamization and terrorism in 1983. According to Fluehr-Lobban (1991: 71), 'Sudan has offered one of the more provocative cases of state-supported Islamization in recent years because of the government's swiftness and readiness to apply the hudad punishment after sharia was decreed to be national law in September 1983.' Similarly, the Meles regime soon disbanded the coalition transitional government after it consolidated the Tigrayan-based government and started state 
terrorism as previous Ethiopian regimes. Since this regime emerged from the Tigrayan numerical minority group (estimated at 3.5 million), its terrorism has mainly targeted the Oromo numerical majority (estimated at 35 million), because the Oromo have challenged the Ethiopian racial and ethnic hierarchy and Meles's fake democracy and federalism.

As the Sudanese state currently uses the policies of racism, Islamism, and state terrorism in its attempt to destroy the national movements of the indigenous Africans, the Tigrayan-led Ethiopian regime uses racism and state terrorism to suppress the national movements of the Oromo, Ogaden-Somali, Sidama and others while preaching the rhetoric of 'democracy,' 'federation,' and 'self-determination' to establish the hegemony of the Tigrayan ethnocracy. Ethiopia and Sudan are two of 13 countries in the world that face the threat of genocide; the remaining countries are Iraq, Afghanistan, Myanmar, Burundi, Rwanda, the Democratic Republic of Congo, Somalia, Uganda, Algeria, China and Pakistan (Genocide Alert, 2004).

\section{Conclusion}

In Ethiopia and Sudan, state elites have failed in their policies of domination and thus have faced resistance from subjugated ethnonational groups and other sectors. State terrorism and other forms of political repression have intensified crises in these two countries. Global powers that support the authoritarianterrorist regime of Ethiopia oppose the Islamist-terrorist regime of Sudan. The inclination of the Sudanese state to promote Islamic fundamentalism is turning the West against the country. This creates international conditions favorable for the SPLM of the south, and for the SLA and the JEM of west Sudan. This is clearly not the case for the OLF and other liberation movements in Ethiopia. Further, both radical and moderate Arabs are still more comfortable with their Christian Habasha cousins than with indigenous African groups, even though some Oromo are Muslims. As Arab states ignore non-Arabized Muslim Africans in Sudan and Ethiopia, the Christian West ignores the suffering of Christian Oromo and other Christians by siding with Habashas. Neither Christianity nor Islam necessarily helps indigenous Africans to have global or regional connections because of racism; only some southern Sudanese are benefiting from such connections. In their opposition to the Islamist Sudanese state, Europe and North America support the SPLM; they also sympathize with the organizations of western Sudan for political expediency, although they are Muslims.

As the Soviet Union was committed to help the Mengistu regime, the West, particularly the United States, along with some Arab countries, is committed to keeping the Meles regime in power in Ethiopia. The policies of the West have become major obstacles for the struggle for self-determination and democracy in Ethiopia. Similarly, the policies of Arab states have hindered 
to some degree the struggles of south and west Sudan. It is paradoxical that the policies of the West that support the struggle for self-determination in southern and western Sudan ignore the consequences of state terrorism and massive human rights violations in Ethiopia.

Without accountable, democratic, and legitimate governments both in Ethiopia and Sudan, various population groups in these countries may soon face dangerous conditions similar to Bosnia, Rwanda, the former Yugoslavia, and Somalia. If the current Ethiopian state terrorism and massive human rights violations are tolerated by countries that support the Ethiopian government and by international organizations that finance the Ethiopian government - such as the World Bank, the International Monetary Fund, and the United Nations - a disaster is imminent in Ethiopia. The current intervention of the West in the crisis of Sudan may avert the emerging disaster there if western leaders are serious about implementing self-determination and a multicultural or multinational democracy in that country. Regional and global powers, nongovernmental organizations, human rights organizations, responsible and progressive faith communities, and democratic individuals and groups have a political and moral responsibility to expose and fight racism, state terrorism, religious persecution, genocide, and other forms of human rights violations both in Ethiopia and Sudan.

\section{Notes}

1. The Gada system has the principles of checks and balances (such as periodic transference of power every eight years and division of power among executive, legislative, and judiciary branches), balanced opposition (among five parties), and power sharing between higher and lower administrative organs to prevent power from falling into the hands of despots (Legesse, 2000: 2).

2. Historically, Europeans have considered Habashas as a very intelligent people because of their racial affinity with the 'Caucasian race' (Marcus, 1996: 5) and as 'racial and cultural middleman' between black Africa on one side and Europe and the Middle East on the other (Marcus, 1996: 7).

3. According to Hassen (2001: 42):

Only fractions of the Oromo are educated ... By 1995, according to government sources, enrollment was only 20 percent for primary and 12 percent for secondary schools respectively ... Out of an estimated population of thirty million in Oromia 0.1 percent received the third level education in 1994 . . By 2002, all secondary school students in Oromia will graduate from 10th grade instead of the usual 12th grade. Oromo students start learning English in the seventh grade and they 
take [high] school leaving exams in English in tenth grade. Students in Tigray start learning English in second grade and they take [high] school leaving exams in English in 12th grade. They have a better chance of passing [high] school leaving examinations than Oromo students. This means that the Oromo students will not have any more opportunity for college and university level education. Only students in the privileged state of Tigray will have that opportunity in the future. The TPLF dominated regime is deliberately leaving behind Oromo children from the mainstream modern education.

\section{REFERENCES}

Africa Confidential (1997) 38(21) October.

Adams, W.Y. (1977) Nubia: Corridor to Africa. Princeton, NJ: Princeton University Press. Amnesty International (1995/96) Ethiopia: Accountability Past and Present: Human Rights in Transition. Amnesty International.

Beachey, R W. (1962) 'The Arms Trade in East Africa in the Late Nineteenth Century', Journal of African History 3: 451-67.

Bechtold, P.K. (1991) 'More Turbulence in Sudan: A New Politics This Time?', in J.O. Voll (ed.) Sudan: State and Society in Crisis, pp. 1-23. Bloomington: Indiana University Press.

Besteman, C. (1999) Unraveling Somalia: Race, Violence, and the Legacy of Slavery. Philadelphia: University of Pennsylvania Press.

Bulatovich, A. (2000) Ethiopia through Russian Eyes: Country in Transition 1896-1898, trans. R. Seltzer. Lawrenceville, NJ: The Red Sea Press.

Chalk, F. and Jonassohn, K. (1990) History and Sociology of Genocide. New Haven, CT: Yale University Press.

Deng, M. (1991) 'War of Visions for the Nation', in J.O. Voll (ed.) Sudan: State and Society in Crisis, pp. 24-42. Bloomington: Indiana University Press.

The Economist (1997) 'Ethiopia: Federal Sham', 16-22 August, p. 36.

El Mahdi, M. (1965) A History of the Sudan. London: Oxford University Press.

Fossati, B., Namarra, L. and Niggli, P. (1996) The New Rulers of Ethiopia and the Persecution of the Oromo: Reports from the Oromo Refugees in Djibouti. Frankfurt: Dokumentation, Evangelischer Pressedienst Frankfurt am Main.

Fluehr-Lobban, C. (1991) 'Islamization in Sudan: A Critical Assessment', in J.O. Voll (ed.) Sudan: State and Society in Crisis, pp. 71-89. Bloomington: Indiana University Press.

Garang, J. (1985) 'A Historical Perspective on the Sudan', Horn of Africa 8(1): 21-5.

Genocide Alert (2004) 'Iraq, Afghanistan, 11 Other States at Risk of Genocide: Expert', World-AFP, 27 January.

Gramsci, A. (1971) Selections from the Prison Notebooks, trans. Q. Hoare and G.N. Smith. New York: International Publishers.

Hassen, M. (2001) 'Is Genocide Against the Oromo in Ethiopia Possible?', presented at 
the Fourth International Biennial Conference of the Association of Genocide Scholars, 10 June, Minneapolis, MN.

Hizbawi Adera (1996/97) An EPRDF Political Pamphlet, 4(7), December 1996February 1997.

Holcomb, B. (1991) 'Akka Gadaattii: The Unfolding of Oromo Nationalism-Keynote Remarks', in Proceedings of the 1991 Conference on Oromia, pp. 1-10. Oromo Studies Association.

Holcomb, B. and Ibssa, S. (1990) The Invention of Ethiopia. Trenton, NJ: The Red Sea Press.

Human Rights Watch/World Report (1999) 'Ethiopia: The Role of the International Community' [http://www.hrw.org/hrw/worldreport99/africa/ethiopia3.html].

Holt, M. and Daly, W. (1979) The History of the Sudan. Boulder, CO: Westview Press.

Ibrahim, H. (1979) The Shaiqiya: The Cultural and Social Change of a Northern Sudanese Riverain People. Wiesbaden: Franz Steiner Verlag GMGH.

Impact International (1997) 'Cleansing "Islamic Fundamentalism" from the Horn', March.

The International Campaign to End Genocide (ICEG), Genocide Watch (2004) 'ICEG

Letter to Prime Minister of Ethiopia: Massacres of Annuak in and around Gambela', 8 January.

Jalata, A. (1993) Oromia and Ethiopia: State Formation and Ethnonational Conflict, 1868-1992. Boulder, CO: Lynne Rienner.

Jalata, A. (2000) 'U.S.-Sponsored Ethiopian "Democracy" and State Terrorism', in P. Toggia, P. Lauderdale and A Zegeye (eds) Crisis and Terror in the Horn of Africa, pp. 64-8. Burlington: Ashgate.

Jalata, A. (2001) Fighting Against the Injustice of the State and Globalization: Comparing the African American and Oromo Movements. New York: Palgrave.

Jonassohn, K. (1998) Genocide and Gross Human Rights Violations. New Brunswick, NJ: Transaction Publishers.

Legesse, A. (1973) Gada: Three Approaches to the Study of African Society. New York: Free Press.

Legesse, A. (2000) Oromo Democracy: An Indigenous African Political System. Lawrenceville, NJ: The Red Sea Press.

MacKinnon, C. (1994) 'Rape, Genocide, and Women's Human Rights', Harvard Women's Law Journal 17: 11-12.

MacMichael, H.A. (1967) A History of the Arabs in the Sudan, vol. I. New York: Barnes and Noble.

Marcus, H. (1996) 'Racist Discourse about Ethiopia Before and After the Battle of Adwa', presented at the Adwa Conference, 5 March, Addis Ababa University.

Michels, J.W. (1991) 'The Axumite Kingdom: A Settlement Archaeological Perspective', Henok: Journal of Historical and Philosophical Thought 2 (August): 63-72.

Mozersky, D. (2004) 'Sudan Crisis Crying Out for Solution', International Crisis Group, 29 April, pp. 1-2.

O'Ballance, E. (1977) The Secret War in the Sudan, 1955-1972. London: Faber and Faber. 
Oliverio, A. (1997) 'The State of Injustice: The Politics of Terrorism and the Production of Order', International Journal of Comparative Sociology 38(1-2): 48-63.

Oromia Support Group, The 1997 Series.

Oxford Analytica (2004) 'Sudan/Middle East: Arab States Unmoved over Darfur', 13 October.

Prendergast, J. (2004a) 'Sudan's Last Fighting Season?', [http://.crisisweb.org/home/ index.cfm?id=2213\&1=1], pp. $1-3$.

Prendergast, J. (2004b) 'Testimony by John Prendergast to the House Committee on International Relations: Ethnic Cleansing in Darfur; A New Front Opens in Sudan's Bloody War, International Crisis Group [http://.crisisweb.org/home/index.cfm?id= 2213\&1=1] 6 May, pp. 1-2.

Prendergast, J. and Bickel, S. (1994) 'Sudan: Scorched-Earth War', Africa Report (May-June): 38-9.

Scott, W.R. (1993) The Sons of Sheba's Race: African-Americans and the Italo-Ethiopian War, 1935-1941. Bloomington: Indiana University Press.

Sagalee Haraara (1998) The Official Newsletter of Oromia Support Group (December), pp. 1-2.

Sharlach, L. (2002) 'State Rape: Sexual Violence as Genocide’, in K. Worcester, S. Avery Bermanzohn and M. Ungar (eds) Violence and Politics: Globalization's Paradox, pp. 107-23. London: Routledge.

Shiffman, R. (1995) 'Urban Poverty: The Global Phenomenon of Poverty and Social Marginalization in Our Cities; Facts and Strategies' [http://www.picced.org/advocacy/ poverty.htm] (accessed 2003).

Sorenson, J. (1993) Imagining Ethiopia: Struggles for History and Identity in the Horn of Africa. New Brunswick, NJ: Rutgers University Press.

Sorenson, J. (1998) 'Ethiopian Discourse and Oromo Nationalism', in A. Jalata (ed.) Oromo Nationalism and the Ethiopian Discourse, pp. 223-52. Lawrenceville, NJ: The Red Sea Press.

United Nations (1948) Convention on the Prevention of the Crime of Genocide, 9 December, Article II.

Walgren, J. (1994) 'The Lost Boys of Southern Sudan', Africa Report 40 (May-June): 40-1.

Welsh, B. (2002) 'Globalization, Weak States, and Death Toll in East Asia,' in K. Worcester, S. Avery Bermanzohn and M. Ungar (eds) Violence and Politics: Globalization's Paradox, pp. 67-89. New York: Routledge.

Woodward, P. (1994) 'Sudan: State Building and the Seeds of Conflict', in Peter Woodward and Murray Forsyth (eds) Conflict and Peace in the Horn of Africa: Federalism and its Alternatives, pp. 78-85. Brookfield, VT: Dartmouth.

Zia-Zarifi, S. (2004) 'Ethiopia: Halt Crackdown on Oromo Students', Human Rights Watch [http://www.hrw.org/press/2002/05/ethiopia052202.html].

Asafa Jalata is Professor of Sociology, Global Studies, and Africana Studies at the University of Tennessee, Knoxville. He has published two books and edited 
two, namely, State Crises, Globalisation, and National Movements in the NorthEast Africa (Routledge, 2004), Fighting Against the Injustice of the State and Globalization: Comparing the African American and Oromo Movements (Palgrave, 2001), Oromo Nationalism and the Ethiopian Discourse: The Search for Freedom and Democracy (Red Sea Press, 1998), Oromia \& Ethiopia: State Formation and Ethnonational Conflict, 1868-1992 (L. Rienner Publishers, 1993). He has published more than two dozen book chapters and refereed articles. He currently is writing a book entitled Faces of Terrorism in the Age of Globalization: From Christopher Columbus to Osama bin Laden. Address: Department of Sociology, University of Tennessee, Knoxville, TN 37996-0490, USA. Email: ajalata@utk.edu 